\title{
O "trote" e a responsabilidade ética dos futuros médicos
}

\section{The hazing and the ethical responsibility of the future doctors}

\author{
TCBC-SP ISAC JORGE FILHO'
}

É um espetáculo deprimente que se repete a cada vez que são divulgados os resultados dos vestibulares. Futuros médicos assumem papéis lamentáveis e recebem seus novos colegas com calorosas manifestações... de selvageria. O que devia ser momento de alegria pela recepção dos novos colegas se transforma em manifestação bestial de desamor ao próximo. As notícias resultantes dessa "recepção" frequentemente são trágicas: é o calouro que morreu afogado, é o outro que ficou cego, é o que sofreu trauma craniano, é o que teve queimaduras pelo corpo... é um circo de horrores perpetrados pelos que deviam ser a elite cultural do país. E estamos falando de jovens que tiveram o privilégio de serem universitários em meio a analfabetos e semi-alfabetizados. Que fazem parte daqueles que receberam mais, em um país onde a regra é receber menos. A mídia tem divulgado o aumento do número de vagas ocupadas por pessoas mais ricas nos vestibulares de faculdades públicas, mostrando o agravamento da concentração de renda.

A origem do termo tem interessante simbolismo. Classicamente o trote se refere a certa forma de movimentação de cavalos, situada entre o passo e o galope. É processo que deve ser ensinado, muitas vezes por meio de chicote e espora. Lamentavelmente é dessa maneira que o calouro é encarado, em muitas universidades, pelo veterano. A título de "confraternização", ele deve ser "domesticado" por meio de práticas humilhantes e vexatórias, geralmente estimulado por grandes quantidades de bebidas alcoólicas que é obrigado a ingerir, para que simbolicamente "aprenda a trotar". Por incrível que pareça ainda existem defensores do trote, que querem dar a ele a função de rito de passagem ou ritual de iniciação, sendo método para promover a lealdade e a camaradagem do gru- po por meio do sofrimento compartilhado, o que criaria um vínculo entre calouros e veteranos.

Não é assim que deve começar a formação de um médico. Não é assim que deve um universitário, como cidadão, fazer suas manifestações de agradecimento ao sacrifício de muitos para que poucos cheguem à universidade. Os que aí chegam devem ser exemplos de cidadania e não de violência.

Temos proposto uma campanha nacional pela abolição do trote e substituição por recepção civilizada e social ao novo universitário, que já diferencie aqueles que alguns anos depois vão jurar exercer Medicina ética, com zelo e respeito pelos pacientes e pelos colegas. Pouca gente se preocupa com esta proposta. Continuam vendo, passivamente, futuros médicos embriagados participando, forçados ou não, da celebração das diferenças sociais, já que uma das atividades "clássicas" do trote é pedir moedas em esquinas, ocupando o lugar dos infelizes que, lamentavelmente, vivem dessas esmolas.

Questionadas a respeito algumas diretorias de faculdades tem respondido argumentando que o trote está proibido dentro de seus "campi". É bom, mas ainda é pouco. É o mesmo que admitir que, depois de formado, o médico possa cometer barbaridades, desde que não seja no Hospital ambulatório ou consultório.

A maioria dos calouros é contra esse tipo de trote, mas acaba sendo suplantada pela minoria que o admite porque espera, com ansiedade, o ano seguinte para a "vingança".

É fundamental que a categoria médica reconquiste o respeito da população. Não se pode esquecer que o calouro é o futuro médico e o trote selvagem não é maneira correta de se começar o preparo para uma profissão que lida com vida, saúde e ética.

1. Comissão de Ética e Bioética do Colégio Brasileiro de Cirurgiões, Departamento de Bioética e História da Medicina do Centro Médico de Ribeirão Preto. 